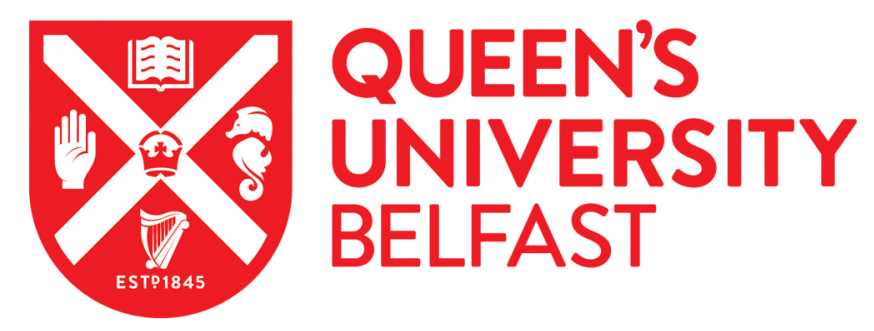

\title{
Plays and Fragments: Antigone, Film, Modernity
}

O'Rawe, D. (2022). Plays and Fragments: Antigone, Film, Modernity. Modernist Cultures, 17(1), [1].

\author{
Published in: \\ Modernist Cultures
}

Document Version:

Peer reviewed version

Queen's University Belfast - Research Portal:

Link to publication record in Queen's University Belfast Research Portal

Publisher rights

(c) 2021 Edinburgh University Press.

This work is made available online in accordance with the publisher's policies. Please refer to any applicable terms of use of the publisher.

\section{General rights}

Copyright for the publications made accessible via the Queen's University Belfast Research Portal is retained by the author(s) and / or other copyright owners and it is a condition of accessing these publications that users recognise and abide by the legal requirements associated with these rights.

Take down policy

The Research Portal is Queen's institutional repository that provides access to Queen's research output. Every effort has been made to ensure that content in the Research Portal does not infringe any person's rights, or applicable UK laws. If you discover content in the Research Portal that you believe breaches copyright or violates any law, please contact openaccess@qub.ac.uk. 


\title{
Plays and Fragments: Antigone, Film, Modernity
}

\author{
Des O'Rawe,
}

\begin{abstract}
[Within the history of modernity, the tragic shape and ethical concerns of the Antigone myth have made it a vital touchstone for understanding contemporary cultural and political realities. This essay traces the modernist processes of adaptation, citation, displacement, and revision that have often characterised the relations between filmmakers and this foundational myth. Focussing on those films that subvert the authority of narrative realism and the laws of conventional-'classical' - film language, it discusses how particular social contexts and commitments have inevitably constructed different images of Antigone-how the Antigones that emerge in early or 'silent' cinema, for example, compare with those from other film and media forms, including television, video and installation art works.
\end{abstract}

Keywords: cinema - television - myth - film modernism - Antigone and film]

Following a comparative, loosely chronological, approach this essay discusses how the figure of Antigone has presented filmmakers with opportunities to explore the relations between modernity and tragedy. ${ }^{1}$ In particular, it examines how this ancient myth of the perpetual conflict between the state and the individual, compliance and defiance, has lent itself to film modernism; in other words, to concepts and practices of cinema that either pre-exist or consciously resist the institutionalisation of narrative realism, and which are typically associated with both the early or 'silent' era, and the post-war modernist and avant-garde filmmaking traditions. ${ }^{2}$ Meanwhile, if television has often inevitably truncated its 'Antigones' into small-screen stage-plays, the essay also suggests that it too has at times offered productions capable of fulfilling the expressive and democratic potential of that medium. While not claiming to offer an authoritative history of the moving image through its relationship with Antigone, this essay does argue that artistically successful encounters between film and the myth of Antigone have invariably involved subordinating antiquity to modernity, adaptation to experimentation, the banality of content to the politics of form.

\section{War and Peace}

The first documented Antigone film was produced in Rome by Società Italiana Cines in 1911, directed by Mario Caserini. During the 'golden age' of the Italian early cinema (from 1908 to the end of the First World War), a handful of indigenous production companies competed with their French, Danish, and German counterparts for larger, more socially diverse audiences. Throughout this period 
Cines - conscious of Pathé-Frères' growing profile and profits - dedicated itself to 'the constant imitation of the industrial model of French cinema [...], the development and exploitation of the feature film, and the expansion to international markets, especially the US. ${ }^{3}$ Integral to this three-fold strategy was the use of film narratives derived from classical literature and ancient history, films that would 'showcase' Italy's distinctive landscape, its ruins and picturesque vistas. (Italian nationalism was resurgent - especially, during and after the Italo-Turkish War (191112) - and popular culture reflected these trends.) Caserini's film cuvre is typical of the period in being a mixture of literary adaptations (he is sometimes credited with directing the first film version of Othello in 1907 - albeit one more faithful to Verdi than Shakespeare), comedies, and historical epics (on the Risorgimento period, as well as classical Rome). ${ }^{4}$ The defining success of his career, however, was the acclaimed melodrama Ma l'amor mio non muore (Everlasting Love, 1913, Film Artistica Gloria), which became a star vehicle for Lyda Borelli, and presented the Italian cinema with a lucrative alternative to the sweeping historical and biblical epics that tended to characterize its large-scale feature-length productions at this time. ${ }^{5}$ Meanwhile, Caserini's one-reel Antigone - retitled, Gli amori di Emone e Antigone (The Loves of Haemon and Antigone) in 1930, when a soundtrack was added-offered its contemporary audience a short operatic-melodramatic version of the Antigone story, with its heroine silenced as much by the busy theatricality of the mise en scéne as by anything decreed by Creon. These one-reel dramas from classical history and literature also conveyed a nationalist theme, one in which ancient 'Rome' and 'Greece' readily coalesce into a singular heritage, invoking a nostalgia for antiquity and empire while transcending the contemporary reality of Italy's often fraught nation-building project. ${ }^{6}$

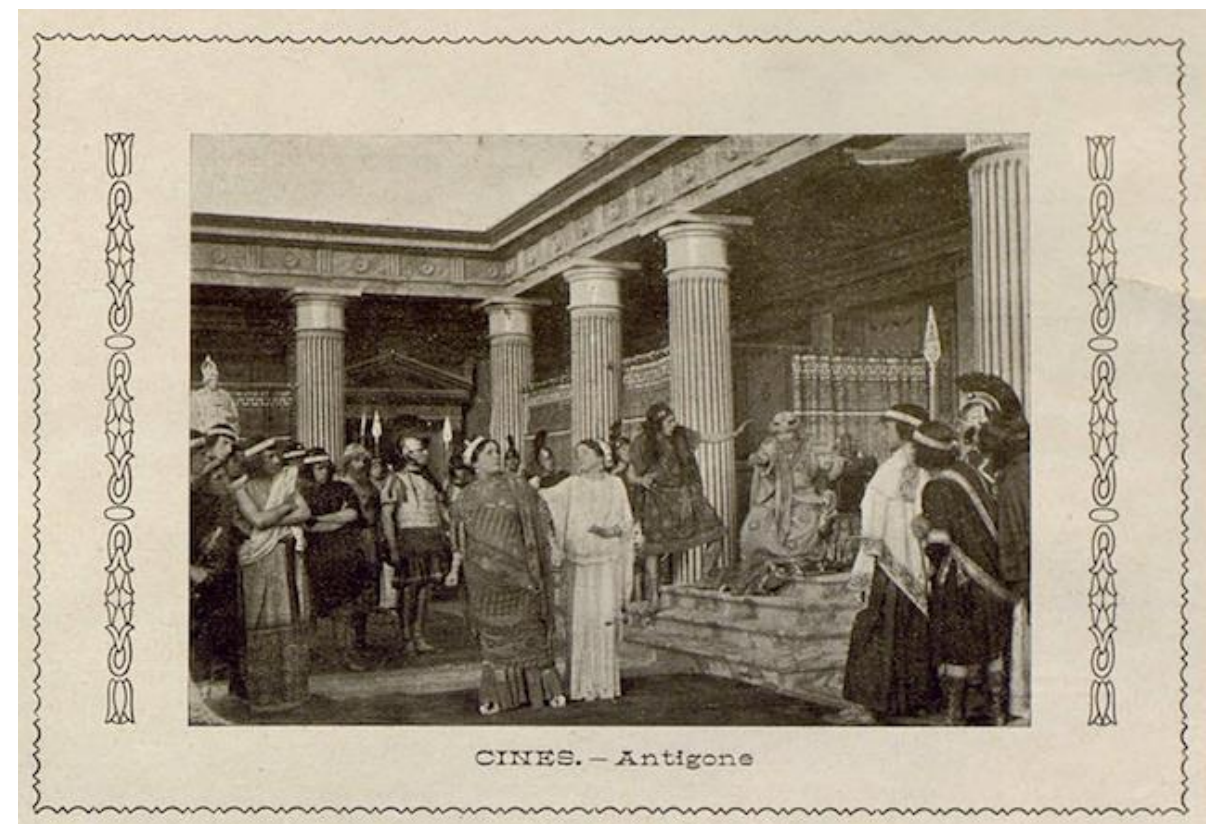


Figure 1. A publicity production still from Antigone (Caserini, 1911), originally published in issue 11 of Arte y Cinematografia, 28 February 1911, 9 (Biblioteca Digital Hispánica). Based in Barcelona, Arte y Cinematografia was the first cinema magazine in Spain.

Another film from the silent era, La Nouvelle Antigone (The New Antigone, Jacques de Baroncelli, 1916) is sometimes assumed to be a version of Sophocles' play, and while its relationship to the original myth is tangential, it is not without significance within the wider context of cinematic Antigones (Figure 2). ${ }^{7}$ Now lost, Baroncelli's film was made by his Paris-based production company, Lumina Films, which typically specialised in short literary and theatrical adaptations. The film was premiered at Lumina's newly acquired studio, and Baroncelli-who wrote the screenplay for the film under his other name, Jacques de Javon- directed Emmy Lynn in the title role. Not to be confused with W.F. Barry's popular Victorian romance novel, The New Antigone (1887) - a three-volume assault on atheism, nihilism, free-love, and the emergence of the 'new woman' - Baroncelli's film had a contemporary wartime scenario, and its Antigone-protagonist was a young, married woman (Edith) who by chance meets and starts to fall in love with her childhood sweetheart (Robert), while her husband (Pierre) is fighting on the Western Front (a part performed in the film by Lynn's real-life husband, Henri Roussell). When Pierre returns home blinded-like Oedipus-from an injury sustained at Verdun, Edith resolves to end her dalliance with Robert, and become a 'new Antigone' by devoting herself to the care of her now invalided husband. ${ }^{8}$

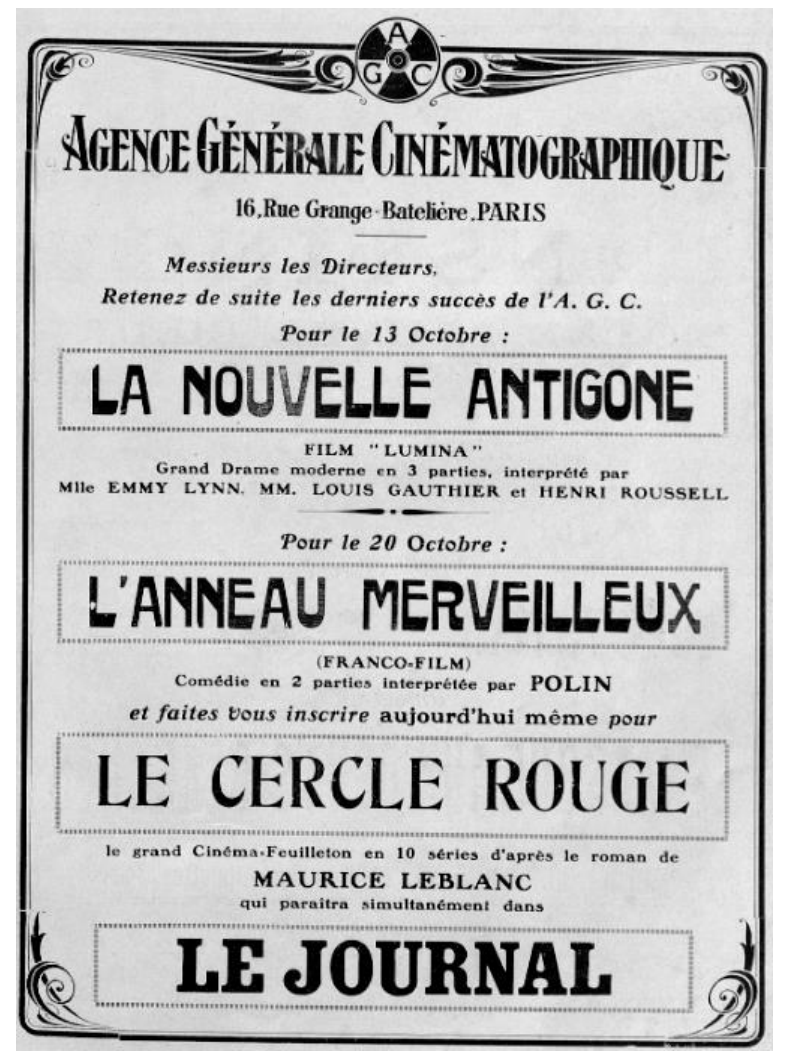


Figure 2: L'Agence Générale Cinématographique (A.G.C.) advertising 'recent successes', including La Nouvelle Antigone (Baroncelli, 1916), published in Le Film, 30 September 1916, no. 29 (BiFi).

Given his association with figures such as Louis Delluc, Marcel L'Herbier, Jean Epstein, and Société Film d'Art, it is likely that Baroncelli's Nouvelle Antigone was influenced by the impressionistic film aesthetic of the day. He arrived at filmmaking through journalism and theatre criticism, and throughout the early part of his career he reviewed films, and debated the question of whether or not film could be classified as 'art'. At the time of La Nouvelle Antigone, for example, he was arguing against the inclusion of intertitles, advocating instead for 'ideal cinema', and writing essays intellectually close to the concerns of influential critics at Le Temps, such as Emile Vuillermoz and Paul Souday. ${ }^{9}$ Within this milieu Baroncelli would almost certainly have been familiar with the writings and radical pacifism of Romain Rolland, who had left France for Switzerland in 1914 - soon to be joined by his friend; fellow émigré, pacifist, poet and Hölderlin enthusiast, Pierre Jean Jouve. Perhaps a shared admiration for the recently 'rediscovered' Hölderlin (Rolland and Jouve were also close to Rilke during his sojourn in Paris before the war), influenced Rolland when he penned his pacifist manifesto, 'À l'Antigone éternelle' (Forever Antigone, 1915), and this polemical intervention in the midst of the First World War (written by the newly crowned Nobel Laureate, no less) - calling on the women of France to save humanity by 'making war on war'-may also have provoked Baroncelli to respond with his own variation on the Antigone motif. ${ }^{10}$

Inspired by patriotism rather than pacifism, La Nouvelle Antigone seems to equate marital commitment with martial valour, rendering social conformity as a form of civic heroism in a time of national crisis. Although the Bibliothèque nationale holds screenplays and various other documents relating to the production of the film (describing it as based on 'un roman de Jacques de Javon'), ultimately one can only speculate on the jingoism of Baroncelli's rendering of this Antigonean scenario, albeit that he is known to have maintained a somewhat aristocratic regard for military honour, empires, and conservative French politicians-especially, during and after the First World War. ${ }^{11}$

\section{Revision and Television}

By the end of the 1920s, the rapid transition to synchronous sound and the growing commercial dominance of Hollywood meant that film versions of Greek tragedies such as the Antigone, Oedipus Rex, or Prometheus were less attractive to studios and screenwriters eager for material that would produce feature-length cinematic 
entertainment; invariably, as cinema audiences became habituated to the identificatory pleasure of narrative realism, they were less in thrall to theatricality and literariness: a 'talkie' was no place for flamboyant dramaturgy or poetically intricate odes. ${ }^{12}$ More broadly, while classical myths and legends might have retained some popular appeal, perhaps the perceived cultural elitism of Classics further deterred a Hollywood now in the business of manufacturing its own homespun mythology of a dynamic young nation founded on individualism, innovation, and ample opportunity. There may also be more pragmatic reasons why commercial cinema seems to have avoided the Antigone during the inter-war period, not the least of which being the problem of representing - or how to not represent the three 'suicides' in the story (Antigone by hanging herself, Haemon plunging into his own sword, and Eurydice repeatedly stabbing herself to death). In discussing the problem of 'the taboo of what cannot be shown and seen' in relation to film versions of Euripides' Medea, Ian Christie, for example, makes a point that might also apply to the Antigone: 'The convention in Greek drama that violent action occurs offstage and is narrated runs directly counter to cinema's imperative to show rather than tell.' His broader argument that filmmakers only directly approached the Medea, for example, in the 'transgressive 1960s' when they were 'unafraid to confront the monstrous feminine or infanticide [...] in a climate in which the political and the psychosexual were in close communion' is also relevant to the cinematic 'rediscovery' of Sophocles' Antigone during that same era, as filmmakers and producers looked for allegorical correlatives to a contemporary culture of heightened civic activism and Cold War anxieties. ${ }^{13}$

In keeping with the educational and wider ideological remit of public service broadcasting in the West in the 1960s and 1970s a variety of original screenplays and contemporary stage productions of the Antigone were adapted for television; quite frequently versions of Anouilh's play, which 'swept through schools, colleges, universities, as well as the amateur and professional theatres of post-war period', and which was also better suited to television and the aesthetic of the small screen than Sophocles' play. ${ }^{14}$ The original English-language version of Anouilh's Antigone was based on Lewis Galantière's translation, and opened in New York in 1946; before being staged at London's New Theatre by the Old Vic Theatre Company in February 1949, a production subsequently broadcast by the BBC in November of that year (produced by Michael Clayton). Ten years later, Michael Elliott also directed a critically-acclaimed theatre production of Anouilh's Antigone for the BBC, which like Gerald Freeman's Antigone, broadcast by PBS for its 'Great Performances' series in 1974, also used the Galantière script. ${ }^{15}$ In 1962, Finland's fledging state broadcaster, STV (Suomen Televisio), also televised Anouilh's Antigone, directed by Tom Segerberg; as did CBC (Société Radio-Canada), for its 'Jeudi-Théâtre' series (directed by Louis-Georges Carrier). In the same year, Ton Lutz adapted his recent Rotterdam Toneel production of Christopher Logue's Antigone for AVRO (Algemene Vereniging Radio Omroep), based on a translation by the controversial Flemish poet and writer, Hugo Claus. Interestingly, there were also two major productions during 
this period that harked back to the 1930s: in 1960, Hans Dahlin directed an Antigone for Swedish television, based on a 1934 radio adaptation by Hjalmar Gullberg, the Scandinavian poet and a prodigious translator of classical Greek drama throughout the 1930s; and in 1964, Pavel Hobl's surrealist version of a revised version of Iša Krejčís 1933 cantata, Antigona: Scénická kantáta podle Sofoklovy tragédie (Antigone: After the Tragedy by Sophocles), was originally screened on Czech state television, before being distributed internationally as representative of the emergent Czech New Wave cinema movement. ${ }^{16}$ In keeping with the general tendency to modernise Greek tragedies by divesting them of any supernatural or cosmic dimension, Per Bronken also availed of the aesthetic possibilities afforded by the small screen to direct his own naturalistic version of Sophocles' Antigone for Norwegian television-which was eventually broadcast in 1970 by NRK (Norsk rikskringkasting).

French television also produced several notable versions of the Antigone during this period, for example: Jean Cocteau's Antigone was produced by JeanClaude Nesle in 1966, and broadcast by ORTF (Office de Radiodiffusion-Télévision Française). ${ }^{17}$ In 1973, Jean-Paul Carrère produced a two-hour version of Jean-Pierre Miquel's recent Théâtre de l'Odéon production of Brecht's Antigone-Modell 1948 for ORTF; and the following year Stellio Lorenzi directed another Antigone (also for ORTF), featuring Marie-Hélène Breillat in the title role. Lorenzi, who had been an assistant director to Jacques de Baroncelli for the production of La Rose de la Mer (1946), claimed he had based his script largely on an 1830 French translation of the play. ${ }^{18}$ Interestingly, in 1972, Margot Thyret directed a version of Piet Drescher's contemporary Leipzig stage production of Antigone for GDR state television, a production not based on Brecht's Antigone-Modell 1948 but rather on another nineteenth-century metrical translation: Johann J. Donner's 1839 version, which had famously been staged to music composed by Felix Mendelssohn in 1841 (a choice perhaps influenced by the fact that Drescher had recently parted company with the Berliner Ensemble, and was now working at Karl-Marx-Stadt (Chemnitz) with Gerhart Meyer and Hartwig Albiro). ${ }^{19}$ The Italian filmmaker, Vittorio Cottafavi managed to direct two television Antigones during his career, both based on a translation from Sophocles by the classicist, Enzio Cetrangolo, and produced for RAI (Radiotelevisione italiana). Cottafavi's first Antigone (1958) is not especially remarkable, and the closely framed faces, gestures and costumes of the leading actors struggle to transcend the tawdry studio set, and the grainy black-and-white definition of RAI productions from that era. ${ }^{20}$ The second Antigone was broadcast in 1971, and belongs to his more aesthetically ambitious trilogy of television adaptations from classical Greek theatre, the others being Le troiane (The Trojan Women, 1967) and I Persiani (The Persians, 1975). These films also reflect the role of television as a valued source of social and cultural education during this period, and its appeal to other contemporary Italian filmmakers in this regard (most notably, Rossellini, but also emerging figures such as Liliana Cavani and Marco Ferreri). Clearly influenced by Brecht, as well as Pasolini's 1967 Edipo re (Oedipus Rex), Cottafavi shot his second Antigone in the open air-among the ancient Greek ruins, 
and the traffic, tourists, and parked cars at Paestum in Salerno-and included disruptive and self-referential documentary techniques, emphasising the fact of performing the Antigone in Italy at this time to reflect on contemporary relations between myth, modernity, art and mass culture.

\section{Nostalgia and Dystopia}

In terms of the cinema, there were two major feature film versions of the Antigone in the 1960s: Georges Tzavellas' 1961 Greek-language version of Sophocles' play; and Cavani's elaborately allegorical I cannibali (The Cannibals, 1969). Although less wellknown than other contemporary (Euripidean) films from this era-i.e. Ilektra (Electra, Michael Cacoyannis, 1962) and Jules Dassin's English-language Phaedra (1962)Tzavellas' film similarly aimed at popularising classical Greek theatre through cinema. To this end, it dutifully adopts the conventions of Hollywood narrative realism, characterised by expressionistic cinematography that includes numerous P.O.V. and shot/reverse shot variations, as well as formulaic high and low-angle shots, and motivated flashback sequences.

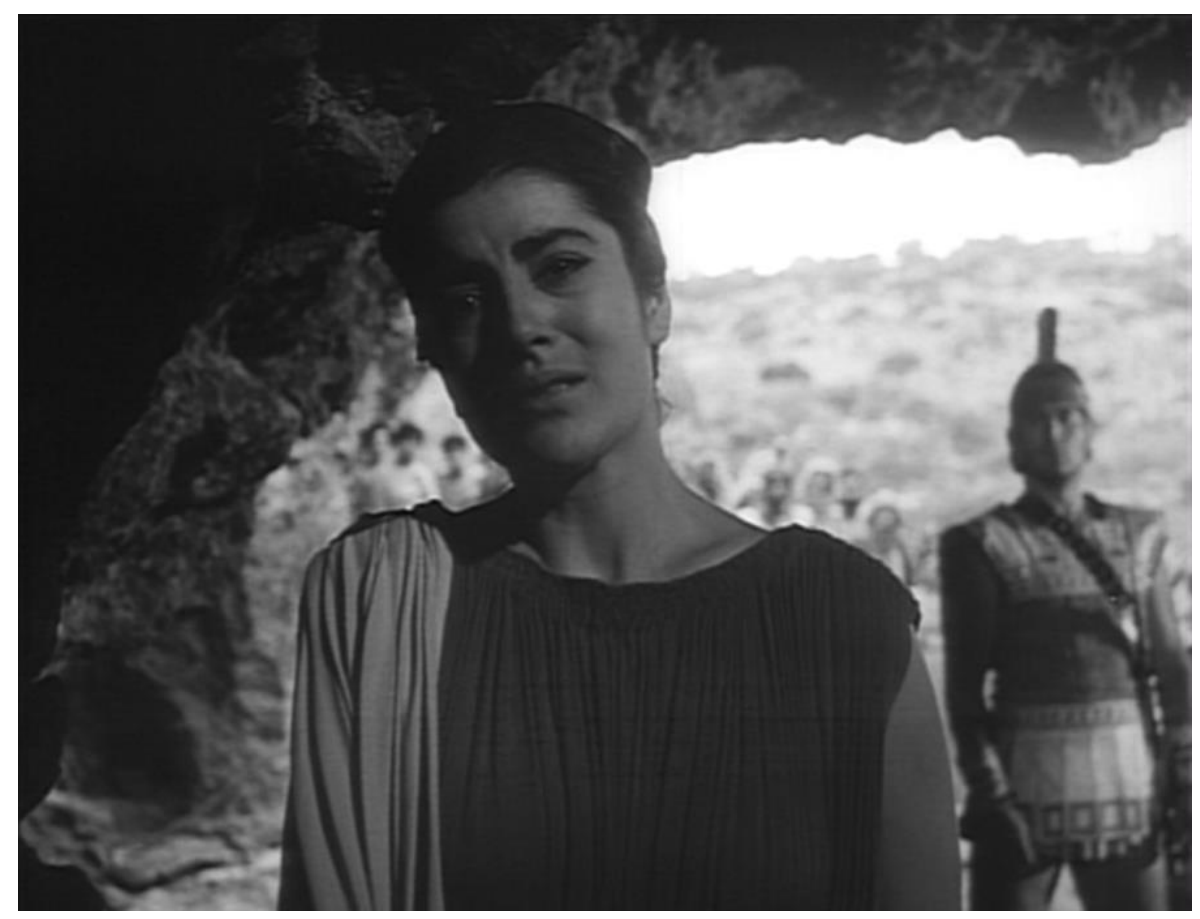

Figure 3: Screen shot from Antigone (Tzavellas, 1961), featuring Irene Papas (Antigone), a film that endeavoured to translate the 'Greekness' of Sophocles' play into the language of contemporary Hollywood. 
The soundtrack is atmospheric, unobtrusive, and derivative of 'sword and sandal' or peplum films; while the inclusion of a voice-over narrator, and Tzavellas' preference for contemporary vernacular language, and the avoidance of masks, song and choreography (with the questionable exception of one scene in which a young woman entertains Creon and his court by playing a double-reed aulos), further accentuates the film's formal conservatism. Some aspects of the mise en scène do appear to gesture towards a more filmic reimagining of Sophocles' play, such as the sequences shot on location on the outskirts of Athens (especially, the messengerguard's soft-focus flashback to Antigone (Irene Papas) performing the burial rites over the corpse of Polynices, or her entombment and final speech which calls to mind the cinematic staging and double-framing techniques characteristic of contemporary Hollywood (The Searchers (John Ford, 1956), for example, or Orson Welles' formally influential Shakespeare films (Macbeth (1948) and Othello (1951)) but ultimately Tzavellas was more interested in narrational transparency and cultural capital than making any meaningful contribution to the politics of film form.

Given his post-war career as a director (and writer) of melodramatic and light comedy films, and background as a playwright, it is perhaps not surprising that Tzavellas' Antigone would rely on naturalistic performance styles and conventionally realistic editing and shot structures, or that it so readily melodramatises the Antigone/Haemon relationship and leaves little scope for nuance and ambiguity. In the wake of the Second World War and a civil war in Greece that only 'officially' ended in 1949, Tzavellas' outlook was characterised by misgivings about his country's accelerating economic development in the 1950s, and a nationalist concern for the survival of Greece's indigenous performance traditions and cultural life in the wake of post-war modernisation. Vrasidas Karalis, for example, while generally appreciative of Tzavellas' achievements as a film-maker and sympathetic to the challenges he faced in attempting to develop a distinctively Greek cinema during this period, nevertheless notes the director's sentimental, reactionary attachment to a social vision unmarked by class conflict, urban planning, or the complicated legacy of civil war, offering audiences in popular films such as $O$ methystakas (The Drunkard, 1950) or Istoria mias kalpikis liras (The Counterfeit Coin, 1955) 'a community still holding on to its values, but with the cracks and the ruptures imposed by a modern capitalist system becoming more obvious and destructive [...] Tzavellas' gaze tried to restore human emotions to their pristine premodern purity.' ${ }^{21}$ In this case, rediscovering Sophocles' Antigone at this moment in the history of modern Greece was consistent with a socially conservative attitude to change, instability, and uncertainty.

Throughout the 1950s and 1960s Greek governments lurched from one unstable centre-right coalition to another, with the military shuffling ominously on the political fringes (culminating in the coup of 1967, and the seven-year 'Regime of the Colonels'). A strategically important Cold War country, Greece joined NATO in 
1952 (and remained a client-state of the US until the Papandreou governments of the 1980s), and political debate in the late 1950s was dominated not only by attempts to resolve the question of Cypriot independence, but also lingering controversies about wartime collaboration, and Greece's imminent membership of the European Economic Community (EEC), which was formally agreed in 1961. In this context, Tzevallas' Antigone is a manifesto for the politics of nostalgia and cultural specificity. There is of course something ironic in this strategy, namely invoking the Antigone as a quintessential symbol of Greek national identity through that international idiom par excellence, the Classical Hollywood style. In contrast, other post-war Greek filmmakers-most notably, Dimos Theos and Nikos Koundourous-returned to Antigone in their work but to elaborate its allegorical potential rather than to consolidate its cultural caché. Theos' Diadikasia (Proceedings, 1976), for example, renders its take on the Antigone myth in an austere, experimental cinematic style, preferring fragmented forms to coherent stories in its indictment of the political cover-ups and culture of half-truths that followed the 'Regime of the Colonels', while Koundourous weaves strands of Sophocles' play into the narrative and thematic scheme of I Fotografoi (The Photographers), his 1998 feature film set in a contemporary war-torn Islamic country (presumably, Afghanistan) that endeavours to 'blend feminism with pacifism ... [to explore] alternative modes of communication which transcend cultural barriers and resist the commodification of violence and suffering. ${ }^{22}$

If Tzavellas' sensibility and film style tended towards conventionality, Cavani's approach in I cannibali was informed by a markedly different concept of cinema. For Cavani, reimagining the Antigone story involved unleashing its disruptive energies, especially at a time when a youth culture radicalised by the events of '1968' was now confronting the reassertion of state power (a situation that was inevitably sowing the seeds of Italy's 'Years of Lead' or Anni di piombo). While not disassociating I cannibali from the counter-cultural politics of the time, however, Cavani did not want her film to be interpreted propagandistically as 'the chronicle of a revolution', a revolution she felt that had become undermined by its own bombast: 'The idea of the film originated during the great Babel of 1968, when language became meaningless. I wanted to make a film against these kinds of speeches and restore the value of silence and pure gesture, gesture as word. And I also wanted to reclaim an ethical order. Sophocles believed in an inherent, ethical nucleus of reality. ${ }^{23}$ Despite the moralistic tenor of such sentiments, and a preoccupation with dramas of manipulation and control, Cavani's films do not constitute an aesthetically or ideologically consistent cuvre, nor in I cannibali is 'the woman's movement aggressively manifest', as has been carelessly assumed. ${ }^{24}$ In fact, if anything, some feminist critics have commented on 'the apparent inattentiveness to sexual difference' in her work, with I cannibali being no exception in this regard. ${ }^{25}$ This is, after all, the same director whose filmography includes: two films based on the life of St. Francis of Assisi (1966, and 1989); another on an eleventh-century mystic (1973); one depicting Friedrich Nietzsche's descent into madness (1977); 
and-controversially - a film that centred on a relationship between fascism, sadomasochism and the Holocaust (Il portiere di note (The Night Porter, 1974); and a mainstream popular thriller, Ripley's Game (2002). Indeed, the visual style of I cannibali, with its sterile cityscape strewn with corpses, cold colour palate and frenetic hand-held cinematographic pace may also owe something to various Italian dystopian or apocalyptic Sci-Fi films of the late 1960s, such as: Il seme dell'uomo (The Seed of Man, Marco Ferreri, 1969); Ecce Homo: I sopravvissuti (Ecce Homo, Bruno A. Gaburro, 1969); or H2S (Roberto Faenza 1969).

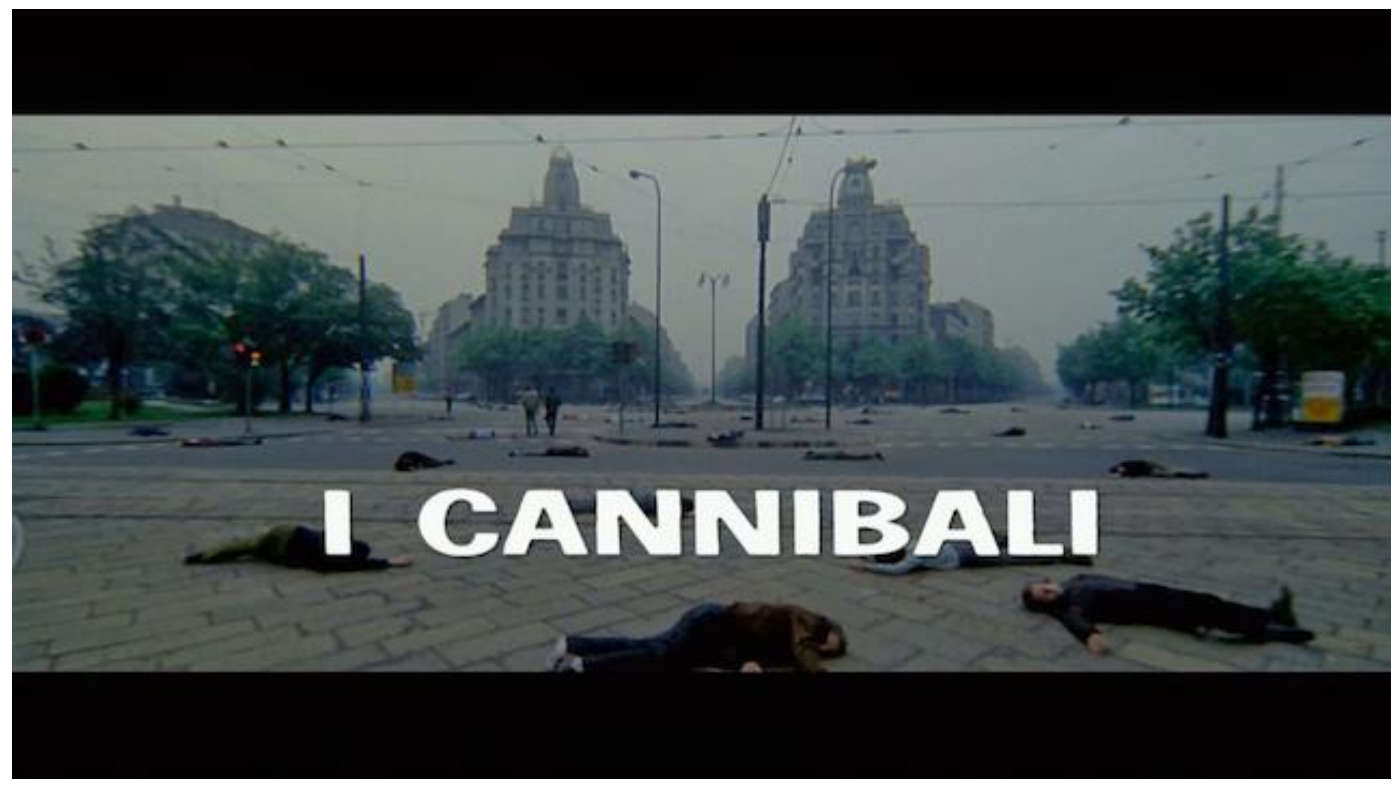

Figure 4: Executed 'enemies of the state' left unburied on the city streets in this screen shot from the opening title sequence of I cannibali (Cavani, 1970).

Although the narrative of I cannibali broadly follows that of the traditional Antigone story, Cavani relocates the action to a recognisably contemporary city (Milan) under martial law; a city in which dissidents and radicals are being summarily executed, and where burial is being refused to these so-called enemies of the state. The film offers a complex, ironic vision of the bureaucratic madness of state repression, and the complicity of ordinary citizens in legitimising and normalising judicial violence, establishing a direct association between Italy's not so distant fascist past and its increasingly authoritarian-Christian Democrat-present. Cavani expands the role of Tiresias (Pierre Clémenti), who arrives in the city as kind of mystic or messiah, and who, instead of being blind, speaks a strange, incomprehensible language. For much of the film, Tiresias and Antigone are comrades-in-arms, communicating with one another through mime-like gestures and silence. Although the extensive use of telephoto and hand-held reaction shots gives the mise en scène a faux-documentary quality, some of film's stylistic influences 
also come from beyond cinema and television. When Kaja Silverman, for example, suggests that 'Cavani's cinema would seem to be fuelled by the dream of androgyny', and the recurrence of characters 'undressing', what also comes to mind in relation to this aspect of I cannibali is Guillaume Apollinaire's Les Mamelles de Tirésias (Breasts of Tiresias, 1917), a seminal work of surrealist theatre that associates androgyny with language, and feminism with pacifism. ${ }^{26}$

Cavani specialised in documentary as a student at Centro Sperimentale di Cinematografia and began her career making historical documentaries for RAI, while also being involved in contemporary avant-garde theatre at this time. I cannibali, for example, draws on theatrical forms and gestures influenced by Gruppo 63, the Italian anarchist-surrealist literary collective. Cavani was one of the twenty signatories to the 1966 manifesto, 'Per un convergno sul Nuovo theatre'/'Towards a Conference on New Theatre', originally published in Sipario, the theatre review edited by Franco Quadri. Both the manifesto and the subsequent conference in Ivrea in 1967 denounced Italy's mainstream theatre of bourgeois complacency, advocating instead experimentation and social engagement in the manner of the Living Theatre (which had been resident in Rome in the mid-1960s), and was soon to inspire figures such as Eduardo De Filippo and Eugenio Barba; and Dario Fo, whose theatre, as Quadri remarked, had turned increasingly towards 'a type of spectacle integrating mime with song, deft theatrical mechanisms with one eye on the circus, but above all with a tightrope stretching back to commedia dell'arte. ${ }^{\prime 2}$ During the extended 'chase sequence' in I cannibali, for example, in which Antigone (Britt Ekland) and Tiresias are being pursued by soldiers, she is draped in a white blanket while he has a red blanket wrapped around him, an image that evokes the clown couples or doubles from the traditional Italian circus, while mime, muteness and gesture characterise their acting styles throughout, emphasising the profoundly disruptive, alienated nature of their refusal to communicate, to subordinate gesture to speech: 'the dialogic nature of Tiresias and Antigone's silence generating a mythopoiesis of polyphonic acoustics in [I cannibali]. ${ }^{28}$

\section{Romantics and Radicals}

Not surprisingly, television productions of the Antigone had a particular social resonance in West Germany, where the politics of the Cold War (work on the Berlin Wall began in August 1961) coincided with and encouraged terrorism (the firebombing of two Frankfurt department stores in 1967 was the first serious act of what would soon become the Baader-Meinhof group and Red Army Faction (RAF)). In 1960, Fritz Schröder Jahn directed a modern version by Claus Hubalek, Die Stunde der Antigone as part of a season of weekly 'teleplays' produced by NWRV (Nordund Westdeutsche Rundfunkverband); a season that included a production of Hamlet (1960), directed by Franz Peter Wirth, who would also direct a television 
adaptation of Anouilh's Antigone in 1965 (Bavaria Atelier GmbH/WDR) - a play previously adapted for West German television by Franz Josef Wild in 1958 (Bayerischen Rundfunks (BR)). One of William Dieterle's last films was also an Antigone for West German television in 1962 (Hessischer Rundfunk (HR)), adapted directly from a recent performance at the Bad Hersfeld Festival and based on the Hölderlin translation; in addition to his long association with Brecht (especially, during the latter's difficult sojourn in Hollywood in the early 1940s), Dieterle (who, like Dassin, had been blacklisted in the 1950s) had played Creon in the world Premier of Hölderlin's Antigone in 1919, directed by Josef Danegger at the Stadttheater Zürich. ${ }^{29}$ In 1968, Rainer Wolffhardt directed an adaptation of Rolf Hochhuth's 1963 novella, Die Berliner Antigone, for ZDF (Zweites Deutsches Fernsehen). Similarly influenced by Brecht's Antigone-Modell and Erwin Piscator's 'documentary theatre' techniques, Hochhuth set his revised version of the play in wartime Berlin, intending it as both a homage to those German citizens who had died actively resisting the Nazis and an indictment of the FRG's piecemeal attempts to bring former Third Reich judges and prosecutors to justice. Hochhuth also wanted to draw attention to the complicity of the medical sciences in legitimising the Nazi regime: his protagonist's crime is to retrieve her executed brother's corpse from the Berlin Institute of Anatomy and bury him in the municipal cemetery. Hochhuth's wife at that time, Marianne Heineman-Sideri, was the daughter of Rose Schlöinger, who had been executed in 1943 (as a member of the Red Chapter resistance group) and her corpse was dissected by a 'Nazi anatomist', Hermann Stieve. ${ }^{30}$ It is also worth noting in this context that Ula Stöckl's first significant foray into filmmaking was her Antigone (1964), an experimental short, and the Living Theatre's neo-avantgarde interpretation of Brecht's version (of Hölderlin's version) of Sophocles' Antigone was also filmed and distributed in the late 1960s; first performed in Krefeld, North Rhine-Westphalia, in February 1967, the performance was based on a script by Judith Malina (who had fled Germany as a child with her family in the late 1920s to escape antisemitism, and had first translated Brecht's Antigone-Modell in a New Jersey county jail, while serving a one month sentence in 1963 for contempt of court).

Regardless of the public status of television during this era and the popularity of televised productions of classic European plays, the Antigone inevitably encouraged a wider reassessment of the legacy and culpability of the Romantic tradition within German culture, and why the philosophical questions dramatized in Sophocles' play-and classical tragedy, more generally - had proved so influential in the formation of German nationalism, or as Thomas Elsaesser puts it: 'Antigone's name trails with it an entire post-Romantic politics of interpretation. ${ }^{31}$ These issues acquired an added poignancy in the Federal Republic with the eruption of political violence in the 1970s, including the state's draconian response to these seemingly exceptional times-increased media censorship, intensified police surveillance, and a refusal to address the country's traumatic past. Deutschland im Herbst (Germany in Autumn, Alexander Kluge et al., 1978), a portmanteau film which included episodes directed by Kluge, Rainer Werner Fassbinder, Volker Schlöndorff and several others, 
aimed to use cinema to criticise the repressive actions of the authorities. Combining dramatic sequences with contemporary documentary and news footage, Deutschland im Herbst was edited by Kluge and Beate Mainka-Jellinghaus from nearly ten hours of film. The series of individual episodes or vignettes is framed by documentary and news reports from two funerals - that of Hanns-Martin Schleyer (the prominent industrialist and former SS member, who was kidnapped and then murdered by the RAF), and the joint funerals of Andreas Baader, Gudrun Ensslin, and Jan-Carl Rasp (the three leading members of the RAF who committed suicide while being held in Stuttgart-Stammheim prison, just over a year after Ulrike Meinhoff had been found hanged in her cell). Schleyer's family was afforded a lavish state funeral, attended by various political and cultural dignitaries (several whom had also been former Nazis), while the joint funeral of the three terrorists was a shambolic media circus, used by the police to photograph mourners or detain RAF sympathisers.

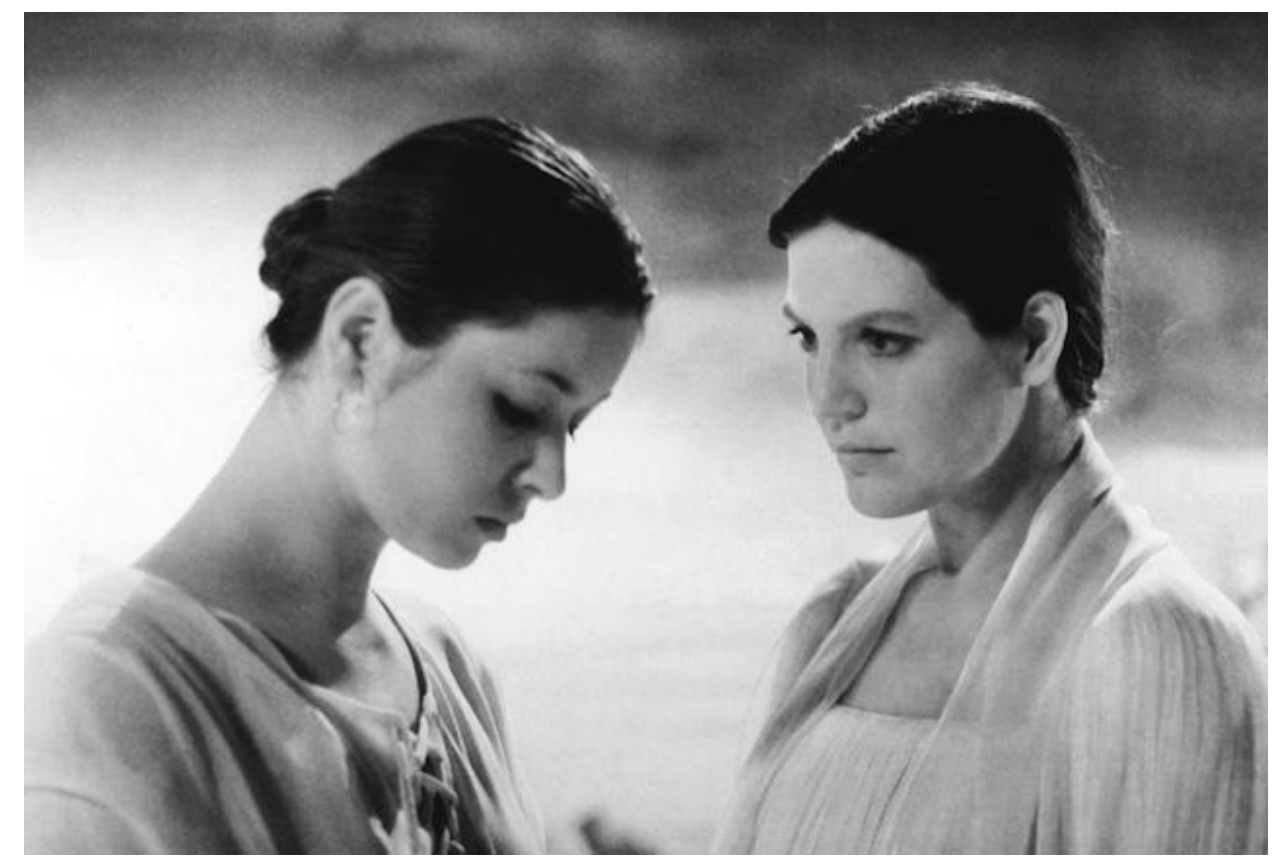

Figure 5. Screen shot from the 'Die verschobene Antigone' episode from Deutschland im Herbst (1978), featuring Antigone (Angela Winkler) and Ismene (Franziska Walser), in which Antigone's justification resonates in the debate between the television company executives and the filmmakers.

A key episode in the film, 'Die verschobene Antigone' ('The Rescheduled Antigone'), directed by Schlöndorff and based on an original story by Heinrich Böll, depicts a group of TV executives deliberating with two filmmakers over whether they should broadcast their television version of the Antigone, which the broadcasting company had commissioned for a series, 'Youth Meets Classics'. Considering current events, however, the executives suggest the play is now problematic, and its themes-burial, resistance ('women terrorists'), and suicidemight encourage young, impressionable West Germans to sympathise with the terrorists. There follows a farcical debate about versions of a possible 'disclaimer' 
and the ambiguity of language more generally before the executives decide the Antigone is potentially too incendiary to broadcast, preferring instead a dramatization of episodes from Julius Caesar's Bellum Gallicum. The obvious symmetry of these ironies is not without its limitations, and critics such as Elsaesser and Bonnie Honig have argued that in fact it is Fassbinder's quasi-autobiographical episode (featuring his staged interview with his actual mother) that is perhaps best attuned to the problem of invoking the Antigone myth to frame political events in contemporary West Germany:

[W]here Kluge, in the film as a whole, and Böll and Schlöndorff in their sequence, do all they can to accent the rather remarkable continuities between the contemporary and classical conflicts [...] Fassbinder accentuates the frictions and discontinuities between past and present $[\ldots]$ switches genres, moving from tragedy to melodrama. ${ }^{32}$

Within the wider history of film and television Antigones, of course, there is nothing new about the melodramatic turn, although in Fassbinder's case its motivation is critical rather than commercial-to paraphrase Hans-Joachim Ruckhäberle: in Fassbinder's cinema, Antigone's story is rendered less as the paragon of 'absolute tragedy' than the critique of the absolute. ${ }^{33}$

If the popularity of Anouilh's Antigone reflected a certain existentialist attitude prevalent in the aftermath of the Second World War-a theatre of psychology and introspection rather than one of choreography and action-Brecht's version, while also anti-heroic is however resistant to a politically paralysing or acquiescent notion of tragic fate, and instead emphasises the collective and the social, the war and its devastation as a capitalist-fascist catastrophe. In keeping with the methods synonymous with his name, Brecht 're-models' his sources to create disjunction between audience expectation and theatre experience, an experience of estrangement, defamiliarization, and curiosity rather than one of representation, identification, and transparency. In this context, his choice of Hölderlin's translation of the Antigone was consistent with that concept of theatre: 'long derided as the crazed work of a poet sliding into madness, Hölderlin's is one of the most radical German translations of the play in existence, with its paratactic structure, the attempt to match the syntax as closely as possible to the original Greek, and the introduction of numerous Swabian regional idioms and inflections. ${ }^{34}$ No doubt, Brecht's Swabian upbringing (as much as the broken lines and strange imagery) also attracted him to Hölderlin's poetic language, something that must have sounded both peculiar and yet familiar to his ear; although it also worth bearing in mind he significantly revised or completely excised nearly $50 \%$ of Hölderlin's text. ${ }^{35}$

The salient issue, however, and the one that also interested Fassbinder-and would not have gone unnoticed a decade earlier by Hochhuth and Malina, or Dieterle for that matter-concerns the relationship between German nationalism and 
the idealisation of Greek tragedy or, as in this particular case, the Third Reich's celebration of Hölderlin's 'patriotism' and notion of a near-mystical 'Germania' directly descended from classical Greece, a kindred heroic civilisation enshrining the values of das Vaterländische. However, Brecht's original play is not simply an act of political reclamation intended to subvert the perverse cultural hermeneutics of Nazism by restoring Hölderlin's formal experimentalism and Jacobin sympathies to their rightful place, it is a more wholesale materialist rejection of the humanistic assumption that literature and art can offer points of instructive comparison or hope for the future in the terrible aftermath of the Second World War. As Brecht puts it in his foreword to Antigone-Modell 1948: 'Bourgeois society, with its anarchic system of production, only becomes aware of its own laws of motion in a catastrophe [...] but mere misfortune is a bad teacher.' 36

\section{Texts and Fragments}

As its title indicates, Danièle Huillet and Jean-Marie Straub's Die Antigone des Sophokles nach der Hölderlinschen Übertragung für die Bühne bearbeitet von Brecht 1948 (The Antigone of Sophocles after Hölderlin's Translation Adapted for the Stage by Brecht, 1948, 1991) also approaches the Antigone myth through the lens of various intellectual, theatrical, political and linguistic histories, becoming an invitation to reflect on the poetics of cinema, and the relations between a theatrical performance of Brecht's play (in the Berlin Schaubühne) and the subsequent filming of that same production (performance) in the open-air ancient Greek theatre at Segesta, in Sicily. Although Straub left France for West Germany in 1959 (to avoid being called up for military service in Algeria), the uncompromisingly modernist film method he developed with Huillet owes much to their commitment to cinema history and those formative years spent living in Paris, immersed in its post-war culture of cinéphilie: André Bazin influenced them, as well as Brecht. Never working from original screenplays, their approach to the texts on which their films are based is archaeological and interactive, rather than adaptational in any simple illustrative sense: 'The text becomes a sounding-body, the actor a voice-body, and the film the emancipation of pre-existing literary, theatrical, and cinematic codes, rather than their replacement or interpretation.' ${ }^{37}$ Through the process of filmmaking, Huillet and Straub present the assemblage of cultural histories and hermeneutic possibilities associated with the text. In the case of their Antigone film, for example, what the cinema audience sees in not just a filmed production of the Antigone, but a palimpsestic layering of various 'texts': Brecht's 1948 're-modelling' of Hölderlin's translation from Sophocles, as well as Huillet and Straub's own Berlin stage production (performed in May 1991) before filming in June-July, followed by a final live performance in August, at Segesta: 'a film is most of the time for us an encounter with a place $[. .$.$] when all these elements, the place (space), theatre (fiction), life$ 
(experience) come together, a film is born (time). ${ }^{38}$ While Brecht, Benjamin, and Adorno are important influences in the artistic choices, collaborative practices, and political outlook of Huillet and Straub-for all the supposed austerity, aesthetic restraint, and documentary fastidiousness of their film style, there is also a utopian impulse, one characterised by a 'resolute commitment to a redemptive view of history, and a search for a liberated spectator who could become the historical subject that until now has been obliterated by various modes of oppression.' ${ }^{39}$ This vision of cinema as a process of excavating, sifting, translating, adapting, performing and filming is accompanied by a visual style that holds rigorously to an equality of forms by refusing to privilege specific elements of film mise en scène-whether it be dialogue, acting, sounds, editing styles, etc.

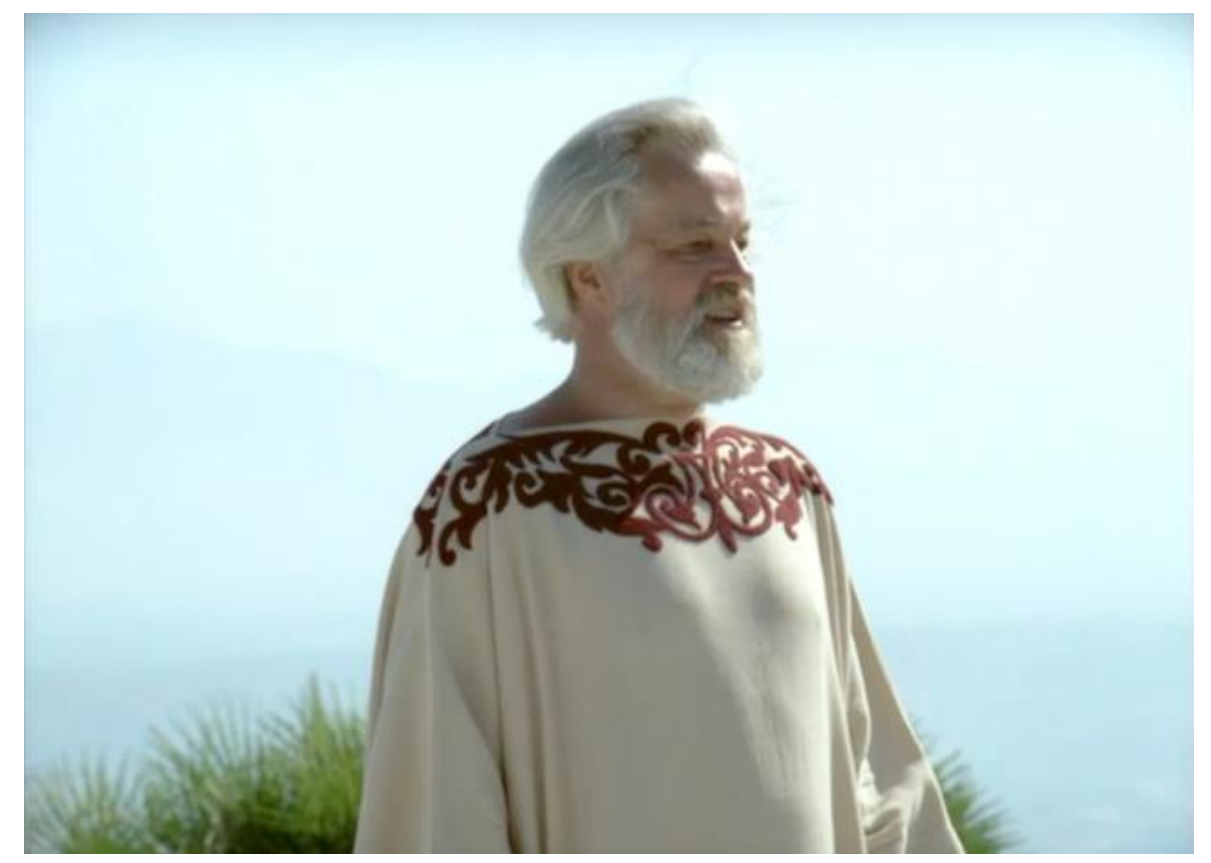

Figure 6. Screen shot from Huillet and Straub's Antigone (1991), in which Creon (Werner Rehm) is framed against an expanse of landscape and sky, accentuating tragic vulnerability in the guise of political authority.

Huillet and Straub's Antigone, for example, is shot from a fixed camera position placed between the skene (stage) and the theatron (auditorium) of the theatre at Segesta, with only limited changes to its direction and elevation. Meaning is conveyed primarily through shot structures rather than montage procedures (the film comprises 147 shots in total). The cinematic staging is more straightforward than in Brecht and Caspar Neher's stage production notes and sketches, with Antigone entering along a line separating her (and other characters) from the chorus (who are positioned at the foot of the theatron) and Creon, who is invariably framed in front of the seemingly boundless Sicilian landscape and surrounding sky. The lighting is completely natural and changes accordingly, and the sound is recorded directly with no post-synch editing or attempt to mute ambient noise (costumes flap 
and flutter in the breeze, voices echo, and movement is audible). The acting styles throughout are, however, non-naturalistic, presentational (or recitational, even) rather than psychologically plausible, and what is being filmed is not so much some polished performance as the processes by which these ('non-professional') actors embody, enunciate and experience the language of their speech.

The opening titles Huillet and Straub's Antigone are accompanied by a 'recomposed' version of Wagner's 'Ride of the Valkyries' from Bernd Alois Zimmermann's Die Soldaten (1958-65), while the film closes with an end-title quotation taken from Brecht's 1952 address to the Peoples' Congress for Peace in Vienna (to the noise of a military helicopter whirling overhead): "The memory of humanity for sufferings borne is astonishingly short. Its gift of imagination for coming sufferings is almost even lesser. For humanity is threatened by wars compared to which those past are like poor attempts, and they will come without any doubt if the hands of those who prepare them in all openness are not broken.' ${ }^{40}$ The choice of text and sound for this epilogue represents a political Parthian shot, finally nudging the film towards more immediate contexts such as the recent reunification of Germany, the 1990-91 Gulf War, and the emergence of capitalism's so-called 'new world order'. If the cinema of Huillet and Straub invariably disconcerts audiences habituated to narrative realism and does not court commercial distributors, neither are their films exercises in minimalism or avant-garde expressionism, as in the case of Stöckl's Antigone or Amy Greenfield's Antigone/Rites of Passion (1990), rather their artistic loyalty is to the formal clarity and photographic qualities of early cinema, the framing of space and time as they are, rather than as they can be made to be by post-production manipulation.

\section{Experiments and Installations}

While Greenfield's cine-dance aesthetic is also indebted to silent film, in the main her artistic and social commitments belong to the post-Second World War feminist tradition within American avant-garde cinema and performing arts, and as such tend to be associated with the work of figures such as Maya Deren, Carolee Schneemann, and Yvonne Rainer. Although released around the same time as Huillet and Straub's film, in formal terms Antigone/Rites of Passion has little in common with its European counterpart. ${ }^{41}$ By no means 'anti-theatrical' in any narrow sense, the film begins with Antigone (Greenfield) stumbling through a forest to Colonus with Oedipus, played by the dancer, Bertram Ross, who also performs the role of Creon in the film (a doubling that serves to emphasise the film's critique of kinship, in that Antigone's father is now not only her brother, but also the same person/performer as her uncle). Foregrounding the movement of the body and physical gesture over speech and dialogue, the film's cine-choreography constantly shapes and reshapes, frames and de-frames, the action and mise en scène. This sense of a highly personal, subjective vision of the tragic universe that Antigone (and her 
kin) inhabits is further underwritten by the film's disjunctive, sometimes jarring, montage formations which include jump cuts and dream-like, associative transitions. These image and sequence structures are complemented by the experimental electronic music and partially acousmatic voices that comprise the soundtrack, accentuating the sense of the Antigone story as being dramatized through these audio-visual elements of film language and dance rather than being adapted from a given literary or theatrical source. This approach also gives added expressive significance to textures, spaces and landscapes: the brutalist concrete solidity of Creon's palace, for example, is clearly in stark contrast to the image of him towards the end of the film, as he clambers-delirious with grief, slipping in and out of the hand-held camera frame-across a steep rocky hillside towards the corpse of his son.

Ken McMullen also approaches the subject of Antigone from a more intertextual and experimental perspective in his 2014 film project, OXI: An Act of Resistance (2014), which was inspired by the frenzy of civic activism that occurred during Greek government-debt crisis in the 2010s, and combines fiction and documentary footage with comments from contemporary European philosophers (Cixous, Balibar and Negri), poetry (Cavafy), and other classical writers (Aristophanes). In the midst of the global financial crisis, McMullen's film invokes Antigone as a touchstone in the struggle against state power and economic injustice. One of his early films, Resistance (1976) - which was produced by the BFI - explored the origins and destinations of various resistance movements throughout the twentieth century (particularly, the French Resistance), and OXI: An Act of Resistance is also a sequel to that film, a revisiting and revising of a political position to ascertain its relevance to the contemporary world. Interestingly, McMullen had also cited Antigone in his Zina (1985) which portrays the final years of Zinaida Bronstein (Domiziana Giordano), Leon Trotsky's traumatised daughter, who lived in forced exile in Berlin before committing suicide in 1933, at the age of thirty-two. The film is structured around her sessions with the eminent Jewish psychiatrist-Professor Arthur Kronfeld (Ian McKellen) - as she increasingly identifies with the figure of Antigone and the fixed tragic shape of her own life.

This practice of fragmenting, augmenting, and reconfiguring the Antigone myth has also proved attractive to visual artists working across video, installation, film and photography; in autumn 2016, for example, the Onassis Cultural Center in New York hosted Antigone Now, a 'festival of arts and ideas [in which] the story of Antigone is seen through the eyes of contemporary artists and thinkers. ${ }^{\prime 2}$ In 2018, Tacita Dean exhibited Antigone, an installation comprising two looped anamorphic films representing a collage or constellation of fortuitous 'Antigone' associations and synchronicities, for example: family (the artist's elder sister, Antigone Dean); theatre (the actor, Stephen Dillane, asking questions dressed as the blind Oedipus); poetry (Anne Carson, answering questions in an historic courthouse in Thebes, Illinois); cinema (tracks of perforations running parallel to the celluloid image, in-camera editing, and the appearance of Rebel Without a Cause screenwriter, Stewart Stern); 
stories (the wanderings of Antigone and Oedipus before they reach Colonus - the 'lost' episode in the Oedipus-Antigone story, which also features at the beginning of Greenfield's film); nature (granite landscapes, Yellowstone geysers); and the cosmos (images of the 2017 'Great American Eclipse'). ${ }^{43}$ Although Dean's film aesthetic is nothing if not available to chance, coincidence and serendipity, her works never simply ruminate on various or random conceptual and thematic preoccupations; there is always an underlying structural-poetic-coherence to her installations. As in Huillet and Straub's Antigone, or Greenfield's Antigone/Rites of Passion, for example, landscape and terrain features as both metaphors and geophysical realities, while the strands of memory, myth and history carefully interwoven throughout Dean's Antigone diptych capture tragedy's tendency to defy any alignment or reconciliation between narrative and time.

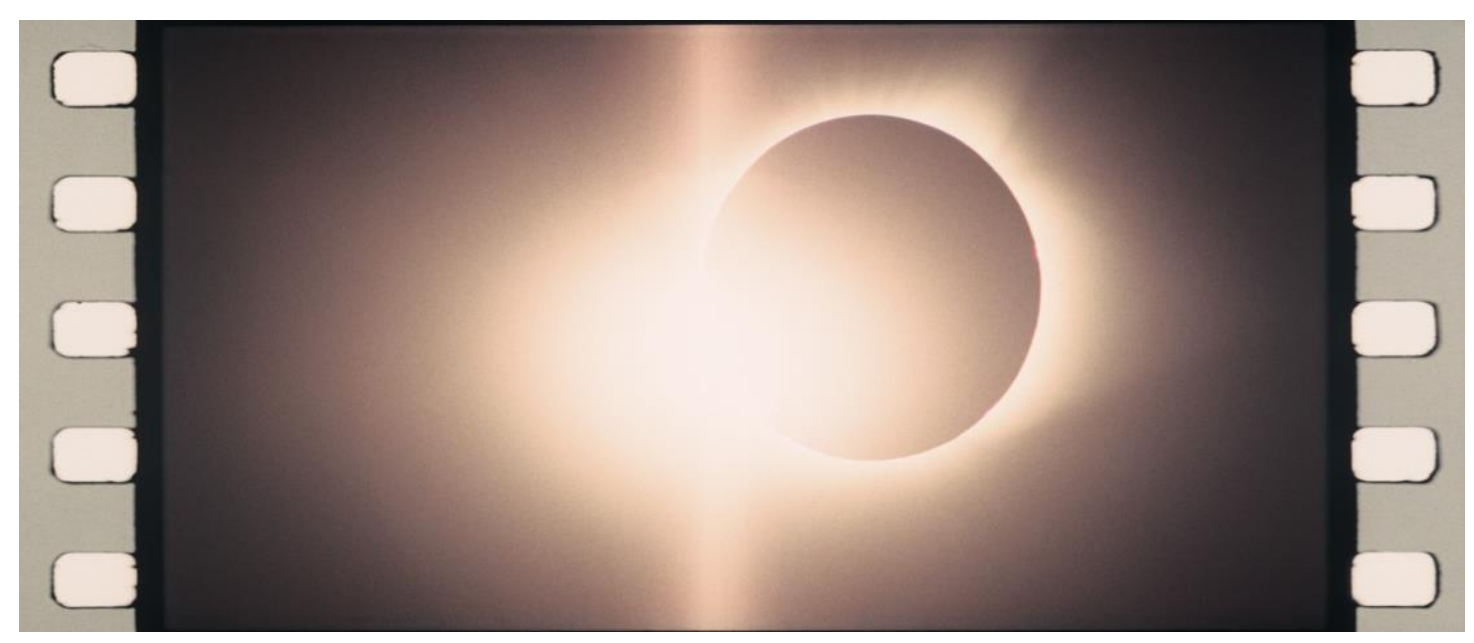

Figure 7. Still from Antigone (Tacita Deane, 2018): Two synchronised 35mm anamorphic colour films, optical sound, with a running time of exactly one hour, continuous loop synced to start on the hour. Courtesy the artist; Frith Street Gallery, London and Marian Goodman Gallery, New York/Paris.

\section{Exodos}

The Antigone phenomenon continues to attract and challenge filmmakers: in the last few years, for example, there have also been a number of widely distributed Canadian, Mexican, and North American Antigone versions and variations. ${ }^{44}$ As Dean's 2018 installation demonstrates, however, innovative approaches to it are also emerging in those spaces that facilitate the imaginative convergence of film and the other visual arts, a convergence that was already being anticipated or at least rehearsed in some of the methods of Huillet and Straub, or Ken McMullen. Primarily, this myth-by its very nature and legacy - continues to invite an interrogation of film style and language, pressurising filmmakers to convey through the expressive resources of their particular mediums not simply complex thematic 
structures and contemporary political parallels but distinctive aesthetic ones as well. Furthermore, rendering anew, revising, or even reinventing the Antigone story in any artistic genre or sphere can surely only be enhanced by an awareness of its relations to cinema, television, and contemporary visual culture and to those defiantly experimental forms and practices, associations and synchronicities, best suited to this task.

\section{Notes}

1. The legend of Oedipus' daughter, Antigone, involves events following the civil war in Thebes, which had ended with the leaders of the opposing sides - Antigone's brothers, Eteocles and Polynices - killing one another in combat. Antigone's uncle, Creon, as the new ruler of Thebes, then decreed that the corpse of the 'treasonous' Polynices be left unburied, outside the city walls. Antigone disobeys this edict and gives her brother a ritual burial - an act which provokes Creon into condemning her to death, even though she is also betrothed to his son, Haemon. The blind prophet, Tiresias, arrives and warns Creon that his behaviour has angered the gods. Creon tries to make amends but too late: Antigone has already hanged herself. On discovering what has happened, Haemon then kills himself in the presence of his father; after which, Creon's wife and Haemon's mother, Eurydice, then also takes her own life. Inconsolable with grief and regret, Creon leaves the city.

2. The use of the term 'film modernism' here implies a distinction between literary studiesorientated approaches to the relationship between cinema and modernism (for example, Susan McCabe, Laura Marcus, Andrew Shail, or David Trotter), and a film studies-orientated approach (which is more evident in work by András Bálint Kovács, Ted Perry, or Sam Rohdie, for example); the conceptual orientation of this essay is more closely aligned with this latter approach, and cognizant of Julian Murphet's comment that ' $[t]$ he very idea one might quibble about which films were, and which weren't, "modernist" has about it the dusty scholastic air of arguments over angels and pinheads.' 'Film and (as) Modernity,' in The Sage Handbook of Film Studies, ed. by James Donald and Michael Renov (London: Sage, 2008), p. 343. See also: Susan McCabe, Cinematic Modernism: Modernist Poetry and Film (Cambridge: Cambridge University Press, 2005), pp. 1-17; Laura Marcus, The Tenth Muse: Writing about Cinema in the Modernist Period (Oxford: Oxford University Press, 2007); Andrew Shail, The Cinema and the Origins of Literary Modernism (London: Routledge, 2012); David Trotter, Cinema and Modernism (Oxford: Blackwell, 2007), pp. 17-48; András Bálint Kovács, Screening Modernism: European Art Cinema, 1950-1980 (Chicago: University of Chicago Press, 2007); Ted Perry, ed., Masterpieces of Modernist Cinema (Bloomington: Indiana University Press, 2007), pp. 1-17); and Sam Rohdie, Film Modernism (Manchester: Manchester University Press, 2015).

3. Giorgio Bertellini, 'Introduction: Early Italian Cinema,' Film History, 12, 3 (2000), 235-239 (p. 237).

4. Robert Hamilton Ball, Shakespeare on Silent Film: A Strange Eventful History (London: George Allen and Unwin, 1968), p. 306.

5. For an analysis of this seminal 'diva film', see Ben Brewster and Lea Jacobs,

Theatre to Cinema: Stage Pictorialism and the Early Feature Film (Oxford: Oxford University Press, 1997), pp. 85-90. 
6. Aldo Bernardini and Vittorio Martinelli, Il cinema muto italiano: i film degli anni d'oro, 1911. Vol. 1a (Turin: Nuova ERI-Edizioni RAI, 1995), p. 39.

7. See, for example, Mythenrezeption: Die antike Mythologie in Literatur, Musik und Kunst von den Anfüngen bis zur Gegenwart, ed. by Maria Moog-Grünewald (Stuttgart: J.B. Metzler, 2008), p. 95; and Maria de Fátima Silva, 'Antigone,' in Brill's Companion to the Reception of Sophocles, ed. by Rosanna Lauriola and Kyriakos N. Demetriou (Leiden: Brill, 2017), p. 463.

8. Bernard Bastide, 'Lumina Films (1915-1917), ou les premiers pas d'un producteur-

Réalisateur,' in Jacques de Baroncelli, ed. by Bernard Bastide and François de la Bretèque (Paris: Association française de recherche sur l'histoire du cinéma, 2007), pp. 51-52.

9. 'À l'Antigone éternelle' was published in a collection of Rolland's pacifist writings,

Au-dessus de la mêlée [Above the Fray] (Paris: Librairie Paul Ollendorff, 1915). Rilke was also close to Norbert von Hellingraph, the driving force behind the publication and reappraisal of Hölderlin's work, who was teaching at the École normale at this time and was subsequently killed in action at Verdun. See Ralph Freedman, Life of a Poet: Rainer Maria Rilke (Evanston: Northwestern University Press, 1998), pp. 391-392. On the relationship between these figures and the Walter Hasenclever's anti-war Antigone (1917), see Rossana Zetti, 'Sophocles' Antigone Reworked in the Twentieth Century: The Case of Hasenclever's Antigone (1917),' New Voices in Classical Reception Studies, 12 (2018), 88-107 (pp. 88-89).

10. Karen Offen, Debating the Woman Question in the French Third Republic, 1870-1920 (Cambridge: Cambridge University Press, 2018), pp. 562-563.

11. See Laurent Véray, 'Baroncelli, cinéaste nationaliste?,' in Bastide and Bretèque, Jacques de Baroncelli, pp. 79-93.

12. For a discussion of production and reception issues relating to the Oedipus myth and early cinema-especially, in relation to The Legend of Oedipus/La Légende d'Oedipe (Gaston Roudès, 1912), see Pantelis Michelakis' Greek Tragedy on Screen (Oxford: Oxford University Press, 2013), pp. 17-34.

13. Ian Christie, 'Between Magic and Realism: Medea on Film,' in Medea in Performance, 1500-2000, ed. by Edith Hall, Fiona Macintosh and Oliver Taplin (Oxford: Legenda, 2000), p. 145. For an authoritative overview of the relations between Greek tragedy and the counter-cultural revolution of the 1960s, see Edith Hall's 'Introduction: Why Greek Tragedy in the Late Twentieth Century?', in Dionysus Since '69: Greek Tragedy at the Dawn of the Third Millenium, ed. by Edith Hall, Fiona Macintosh and Amanda Wrigley (Oxford: Oxford University Press, 2005), pp. 1-46.

14. George Steiner, Antigones: How the Antigone Legend has Endured in Western Literature, Art, and Thought (Oxford: Oxford University Press, 1984), p. 293.

15. See the following (anonymous) reviews: 'A Brilliant Antigone,' The Guardian, October 28, 1959, p.7; and 'A Harrowing Experience: Intense Flavour of Antigone,' The Times. October 28, 1959, p.4.

16. Paul Gray and Erika Munk, 'One Kind of Film-Making: An Interview with Pavel Hobl,' Tulane Drama Review, 11, 1 (1966), 150-153 (pp. 150-51).

17. Cocteau's pared down version was first staged at the Atelier in 1922, with the sets designed by Picasso, costumes by 'Coco' Chanel, music composed by Arthur Honegger, and featuring Genica Athanasiou in the title role (and Artaud as Tiresias). Although Artaud declared during rehearsals that this production had 'restored [Antigone] to its true level of eternal modernism', George Steiner claimed that it was in fact hampered by Cocteau's 'pallid, idiomatic-therefore rapidly dated-adaptation'. Artaud, 'Letter to Yvonne Gilles [November 1922]', in Antonin Artaud: Selected Writings, ed. by Susan Sontag, trans. Helen Weaver (Berkeley: University of California Press, 1988), p. 20; Steiner, Antigones, p. 169. 
18. Jean-Baptiste Jeener, 'Aux Baux: L'Antigone de Lorenzi,' Télé 7 Jours, 762 (December 21, 1974), pp. 8-9. Lorenzi's script is possibly based on Jeanne Champein's version of Sophocles' Antigone, published in her Études Poétique (Paris: Ladvocat Libraire, 1830).

19. For a discussion of the challenges faced by the Berliner Ensemble in the late 1960s and early 1970s (including a reference to Drescher and Albiro's reservations about the Modell), see David Barnett, A History of the Berliner Ensemble (Cambridge: Cambridge University Press, 2015), pp. 199-229, 235-236.

20. See Vittorio Cottafavi, 'Notes pour la mise en scène d'Antigone de Sophocle,' Présence du Cinéma, 9 (1961), 33-40.

21. Vrasidas Karalis, A History of Greek Cinema (New York: Continuum, 2012), pp. 65-66. For a wide-ranging and comparative discussion of Tzavellas' Antigone, see Anastasia Bakogianni, 'All is Well that Ends Tragically: George Tzavellas' Antigone vs. Michael Cacoyannis' Electra', The Bulletin of the Institute of Classical Studies, 51 (2008), 119-67, pp. 136-147.

22. Pantelis Michelakis, 'Greek Tragedy in Cinema: Theatre, Cinema, Politics,' in Hall, Macintosh, and Wrigley, Dionysus Since 69, p. 211.

23. Gaetana Marrone, The Gaze and the Labyrinth: The Cinema of Liliana Cavani (Princeton: Princeton University Press, 2000), pp. 58-59.

24. Steiner, Antigones, p. 150.

25. Kaja Silverman, The Acoustic Mirror: The Female Voice in Psychoanalysis and Cinema (Bloomington: Indiana University Press, 1988), p. 219.

26. Silverman, The Acoustic Mirror, pp. 224-25.

27. Valentina Valentino, New Theatre in Italy: 1963-2013 (London: Routledge, 2017), 8.

28. Marrone, The Gaze and the Labyrinth, p. 10.

29. Marco Castellari, Hölderlin und das Theater: Produktion, Rezeption, Transformation (Berlin: De Gruyter, 2018), p. 243.

30. Rolf Hochhuth and Leopold Ahlsen, Die Berliner Antigone: Erzaehlung und Fernsehspiel (Paderborn: Schoeningh, 1980). Hochhuth's novella was also adapted for Hungarian television in 1968 (Az élö Antigoné/The Modern Antigone, Magyar Televízió), directed by László Nemere.

31. Thomas Elsaesser, 'Antigone Agonistes: Urban Guerrilla or Guerrilla Urbanism? The RAF, Germany in Autumn and Deathgame.' Rouge, 4 (2004): http://www.rouge.com.au/4/antigone.html. [Accessed 15 August 2019]

32. Bonnie Honig, Antigone, Interrupted (Cambridge: Cambridge University Press, 2013), p. 76.

33. Hans-Joachim Ruckhäberle, 'German Antigone,' in Documenta X: Politics, Poetics, ed. by Catherine David and Jean-Francois Chevrier (Kassel: Documenta and Museum-FridericianumVeranstaltungs-GmbH, 1997), 48-53 (p. 50).

34. Daniel Fairfax, 'Straub/Huillet-Brecht-Benjamin-Adorno,' Quarterly Review of Film and Video, 29, no.1 (2012), 34-49 (p. 37), https://doi.org/10.1080/10509200902914879.

35. Robert Savage, Hölderlin after the Catastrophe: Heidegger-Adorno-Brecht (Rochester, NY: Camden, 2009), p. 165.

36. Bertolt Brecht, 'Antigone Model, 1948,' in Brecht on Performance: Messingkauf and Modelbooks, eds. Tom Kuhn, Steve Giles, and Marc Silberman (London: Bloomsbury, 2014), p. 178.

37. Michelakis, Greek Tragedy on Screen, pp. 89-90.

38. Danièle Huillet, 'Supplication!' in Jean-Marie Straub and Danièle Huillet: Writings, ed. by Sally Shafto (New York: Sequence Press, 2016), p. 394.

39. Barton Byg, Landscapes of Resistance: The German Films of Danièle Huillet and Jean-Marie Straub (Berkeley: University of California Press, 1995), p. 233.

40. Byg, Landscapes of Resistance, p. 217. For a discussion of Huillet and Straub's adaptation of Brechtian techniques in their Antigone, see Nenad Jovanovic, Brechtian Cinemas: Montage and 
Theatricality in Jean-Marie Straub and Daniele Huillet, Peter Watkins, and Lars von Trier (New York: SUNY, 2017), pp. 84-92.

41. 'In 1990 [Antigone/Rites of Passion] had its world premiere when it was shown at the Berlin Film Festival-as the Berlin Wall was coming down.' Robert A. Haller, Flesh Into Light: The Films of Amy Greenfield (Bristol: Intellect, 2012), p. 58.

42. See Onassis Cultural Centre, 'Antigone Now: Festival Exploring Contemporary Interpretations of the Ancient Myth', New York, 2016:

https://www.artagenda.com/announcements/184966/antigone-now-festival-exploringcontemporary-interpretations-of-the-ancient-myth [Accessed 2 April 2020].

43. 'Two synchronized $35 \mathrm{~mm}$ anamorphic colour films, optical sound, with a running time of exactly one hour, continuous loop synced to start on the hour.' See Tacita Dean, 'Antigone,' in Tacita Dean: Landscape, Portrait, Still Life, eds. Tacita Dean et al. (London: Royal Academy of Arts, 2018), pp. 90-104.

44. For example: Antigone (Sophie Deraspe, 2019); Antigone (Michael Justin Lee, 2019); and the documentary, Antígona (Pedro González-Rubio, 2018). 